\title{
Evaluation of Efficacy of Azotobacter (AZOMAX) and VAM (ECOMAX-G) on Cotton Yield Attributing Characters
}

\author{
N. K. Patke ${ }^{1 *}$, R. S. Wankhade ${ }^{1}$, A. A. Choudhary ${ }^{2}$ and Sonal Nage ${ }^{1}$ \\ ${ }^{1}$ Agriculture Research Station, Dr. Panjabrao Deshmukh, Krishi Vidyapeeth, \\ Achalpur- 444806, Mahrashtra, India \\ ${ }^{2}$ College of Agriculture, Dr. Panjabrao Deshmukh Krishi Vidyapeeth, Nagpur, India \\ *Corresponding author
}

\section{A B S T R A C T}

A field experiment was carried out to study the efficacy of Azotobacter (AZOMAX) and VAM (ECOMAX-G) on Cotton yield and yield attributing characters at Agriculture

\section{Keywords}

VAM, AZOMAX, ECOMAX-G,

Azotobacter

Article Info

Accepted:

22 July 2020

Available Online:

10 August 2020

Research Station, Dr. Panjabrao Deshmukh Krishi Vidyapeeth, Achalpur, Mahrashtra during kharif season of the year 2018-19 and 2019-20. A set of five treatments consist of Azotobacter (AZOMAX) as seed treatment @ 10g per acre seed quantity $+100 \%$ of recommended "NPK", Azotobacter (AZOMAX) as seed treatment @ 10g per acre seed quantity $+100 \%$ of recommended "PK" \& 75\% of recommended "N", VAM (ECOMAXG)@ $2.0 \mathrm{~kg}$ per acre $+100 \%$ of recommended "NPK", VAM (ECOMAX-G) @ $2.0 \mathrm{~kg}$ per acre $+100 \%$ of recommended "NK" \& 60\% recommended "P" and untreated $(100 \%$ of recommended "NPK") were taken under Randomized Block Design with three replication. The experimental results revealed that among the various treatments, application of Azotobacter (AZOMAX) or VAM (ECOMAX-G) along with 100\% recommended dose of "NPK", produced significantly higher seed cotton yield compared to $100 \%$ recommended "NPK" alone. It is also revealed that $25 \%$ Nitrogen or $40 \%$ Phosphorus fertilizers dose could be saved through use of these biofertilizers without impact on yield and would be more beneficial to the farmers. However, the yield levels under reduced dose of fertilizer along with biofertilizer were at par with $100 \%$ recommended dose of "NPK".

\section{Introduction}

Gossypium hirsutum L. (cotton-white gold) is the king of fibers which provides the basic material for the clothing of man. Cotton plays a dominant role in India's agrarian and industrial economy. With the introduction of Bt cotton, this crop grow in fields with marginal and submarginal fertility levels under dry land farming system in our country. Usually little or no chemical fertilizer is added to this crop and hence characterized by low yield (Koranne, 1996). Hence, there is a need to study the possible ways of improving the yields of this crop.

In this context, Azotobacter sp. a well known PGPR (Plant growth-promoting rhizobacteria) 
has been observed to improve plant growth by production of IAA and fixation of atmospheric nitrogen (Jackson et al.1964, Barea and Brown 1974, Anjum et al., 2007). Plants inoculated with Azotobacter sp. has shown improved seed germination, increase in shoot, root biomass and yield. The beneficial effects have been observed in wheat, rice, maize, millets, mustard, sunflower, cotton and vegetable crops (Malik et al., 2005, Malik et al., 2009, Paul and Paul 2009). The application of Biofertilizer like Azotobacter can fix atmospheric nitrogen which is very much essential for plants growth and yield.

Vesicular-Arbuscular mycorrhizal (VAM) fungi commonly occur in the roots of agricultural crops. The positive effect of VAM fungi on plant growth is through improved nutrients and water uptake by root and increased defenses against soil pathogens (Marulanda et al., 2003). VesicularArbuscular Mycorrhizae (VAM) fungi provides significant amount of nutrients to the plants such as copper, zinc, phosphorus and sulphur by making their widely extended hyphal network on the upper or lower side of the soil layer. Favourable response of vesicular-arbuscular mycorrhizae (VAM) have been noticed by many workers (Tilak and Singh, 1994). VAM fungi (VesicularArbuscular Mycorrhizae) is the most important supplement for the increasing high cost of NPK fertilizer input, into cropping system without substantial loss in yield (Vijayakumar et al., 2000; Tripathi et al., 2005). Because VAM fungi reported to be involved in improvement of plant growth and enhancing accumulation of plant nutrients (mainly phosphorus, zinc, copper and sulphur) through greater soil exploration by mycorrhizal hyphae (Kumar et al., 2001). The use of these biofertilizers may open the new vistas of phosphorus nutrition.
Hence, an experiment was conducted to study the efficacy of Azotobacter (AZOMAXAtmospheric nitrogen fixing bacteria) and VAM (ECOMAX-G) biofertilizer on cotton yield and yield attributing characters.

\section{Materials and Methods}

An agronomic experiment was carried out at Agriculture Research Station, Dr. Panjabrao Deshmukh Krishi Vidyapeeth, Achalpur, Mahrashtra during kharif season of the year 2018-19 and 2019-20. The cotton crop (var. PKV Hy II BG 2) was sown at $90 \times 45 \mathrm{~cm}$ spacing in a gross plot size of $5.4 \times 5.4 \mathrm{~m}$ with a seed rate of 2 to $2.5 \mathrm{~kg} \mathrm{ha}^{-1}$. The crop was raised using RDF @ 120:60:60 kg N:P:K $\mathrm{ha}^{-1}$. The treatments were allotted in field follow the random methods. A set of five treatments consist of Azotobacter (AZOMAX) as seed treatment @ 10g per acre seed quantity $+100 \%$ of recommended "NPK", Azotobacter (AZOMAX) as seed treatment @ 10g per acre seed quantity + $100 \%$ of recommended "PK"\& $75 \%$ of recommended "N", VAM (ECOMAX-G) @ $2.0 \mathrm{~kg}$ per acre $+100 \%$ of recommended "NPK", VAM (ECOMAX-G) @ 2.0 kg per acre $+100 \%$ of recommended "NK" $\& 60 \%$ recommended " $\mathrm{P}$ " and untreated (100\% of recommended "NPK") were taken under Randomized Block Design with three replication. The biofertilizer Azotobacter (AZOMAX) was applied as seed treatment before sowing@10g acre ${ }^{-1}$ seed quantity whereas VAM (ECOMAX-G) was applied as soil application before sowing and mixed thoroughly in the soil @ $2.0 \mathrm{~kg} \mathrm{acre}{ }^{-1}$. Observation on germination percentage, plant height, number of monopodial branches plant $^{-1}$, number of sympodial branches plant ${ }^{-1}$, number of bolls plant ${ }^{-1}$ and seed cotton yield were recorded treatment wise. After boll busting, cotton was picked in two pickings from each net plot and converted into ha ${ }^{-1}$ yield. The impact on seed germination was 
accessed by actually counting the number of seeds germinated from each net plot, impact on fertilizer and yield was analyzed by comparing the seed cotton yields obtained under different treatments. Data obtained during the course of investigation were subjected to statistical analysis by statistical method as suggested by Panse and Sukhatme (1954) in RBD and pooled analysis over two years data were calculated and conclusions were drawn.

\section{Results and Discussion \\ Impact on germination}

Data on seed germination are presented in Table 1. Various biofertilizers, in combination with different fertilizer levels did not influenced the germination of cotton crop in both the years.

\section{Impact on growth attributes}

Pooled means over two years revealed that application of Azotobacter (AZOMAX) as seed treatment $+100 \%$ recommended "NPK" recorded the significantly higher plant height $(127.27 \mathrm{~cm})$ in cotton. However, it remained at par with other biofertilizer treatment and proved significantly superior over untreated control.

Soil application of VAM (ECOMAX-G) at sowing $+100 \%$ "NPK" recorded the highest number of monopodia plant (3.35) and proved significantly superior over other treatments in pooled means over two years.

Pooled Means over two years resulted that soil application of VAM (ECOMAX-G) at sowing $+100 \%$ "NPK" recorded the highest number of sympodia plant (21.60), however, it remained at par with seed treatment with Azotobacter $(\mathrm{AZOMAX})+100 \%$ "NPK"and proved significantly superior over other treatments.
No. of bolls plant ${ }^{-1}$ (32.87) were also recorded significantly higher with soil application of VAM (ECOMAX-G) at sowing $+100 \%$ "NPK", however, it remained at par with seed treatment with Azotobacter (AZOMAX) + $100 \%$ "NPK" and proved significantly superior over other treatments in pooled means.

Such improvement in plant growth of fibre crops due to Azotobacter sp. inoculation in cotton has been reported earlier also (Anjum et al., 2007). Azotobacter is known to improve growth of plant through production of IAA and biologically fixed nitrogen (Hafeez et al., 2004).

Sridevi and Ramakrishnan, 2010 reported similer result in cotton growth attributes like plant height under increased 100 per cent NPK with VAM fungi inoculated plants.

There was significant improvement in plant height, number of flowers and bolls formed, boll weight and seed cotton yield in most of the treatments as compared to uninoculated control reported by Sangeeta Paul et al., 2011 in cotton.

\section{Impact on yield}

Pooled means over two years showed that highest seed cotton yield (2212 $\mathrm{kg} \mathrm{ha}^{-1}$ ) was recorded with soil application of VAM (ECOMAX-G) at sowing + 100\% "NPK" $\left(\mathrm{T}_{3}\right)$, followed by Azotobacter (AZOMAX) as seed treatment $+100 \%$ of "NPK" $\left(2104 \mathrm{~kg} \mathrm{ha}^{-1}, \mathrm{~T}_{1}\right)$ and soil application of VAM (ECOMAX-G) at sowing + 100\% "NK"\& 60\% "P" (2016 kg ha" $\left.1, \mathrm{~T}_{4}\right)$.

However, all these yield levels were statistically at par with each other. Untreated control (100\% recommended "NPK" only, $\mathrm{T}_{5}$ ) recorded the significantly lowest seed cotton yield (1740 kg ha $\left.{ }^{-1}\right)$. 
Table.1 Evaluation of Efficacy of Azotobacter (AZOMAX) and VAM (ECOMAX-G) biofertilizer on growth and seed yield of Cotton

\begin{tabular}{|c|c|c|c|c|c|c|c|c|c|c|c|c|c|c|c|c|c|c|c|}
\hline \multirow[t]{2}{*}{ TrNo } & \multirow[t]{2}{*}{ Treatments } & \multicolumn{3}{|c|}{$\begin{array}{c}\text { Germination } \\
\text { percentage }\end{array}$} & \multicolumn{3}{|c|}{ Plant Height (cm) } & \multicolumn{3}{|c|}{$\begin{array}{l}\text { No. of Monopodia } \\
\text { plant }^{-1}\end{array}$} & \multicolumn{3}{|c|}{$\begin{array}{l}\text { No. of Sympodia } \\
\text { Plant }^{-1}\end{array}$} & \multicolumn{3}{|c|}{ No. of bolls Plant ${ }^{-1}$} & \multicolumn{3}{|c|}{$\begin{array}{l}\text { Seed Cotton Yield } \\
\text { (kg/ha) }\end{array}$} \\
\hline & & $\begin{array}{c}2018- \\
19\end{array}$ & $\begin{array}{c}2019 \\
20\end{array}$ & Pooled & $\begin{array}{c}2018- \\
19\end{array}$ & 2019-20 & Pooled & $\begin{array}{c}2018- \\
19\end{array}$ & $\begin{array}{c}2019- \\
20\end{array}$ & Pooled & $\begin{array}{c}2018- \\
19\end{array}$ & $\begin{array}{c}2019- \\
20\end{array}$ & Pooled & $\begin{array}{c}2018- \\
19\end{array}$ & $\begin{array}{c}2019- \\
20\end{array}$ & Pooled & $\begin{array}{c}2018- \\
19\end{array}$ & $\begin{array}{c}2019- \\
20\end{array}$ & Pooled \\
\hline $\mathbf{T}_{1}$ & $\begin{array}{l}\text { Azotobacter } \\
\text { (AZOMAX) as seed } \\
\text { treatment @ 10g per } \\
\text { acre seed quantity+ } \\
100 \% \text { of } \\
\text { recommended } \\
\text { "NPK". }\end{array}$ & 96.0 & 95.43 & 95.73 & 128 & 126.67 & 127.27 & 3.13 & 3.20 & 3.17 & 21.6 & 18.33 & 19.97 & 32.8 & 28.00 & 30.40 & 2140 & 2067 & 2104 \\
\hline $\mathbf{T}_{2}$ & $\begin{array}{l}\text { Azotobacter } \\
\text { (AZOMAX) as seed } \\
\text { treatment @ } 10 \mathrm{~g} \text { per } \\
\text { acre seed quantity + } \\
100 \% \text { of } \\
\text { recommended } \\
\text { "PK"\& } 75 \% \text { of } \\
\text { recommended "N" }\end{array}$ & 95.5 & 96.59 & 96.03 & 122 & 115.00 & 118.37 & 3.20 & 2.53 & 2.87 & 19.5 & 14.33 & 16.93 & 29.5 & 24.67 & 27.10 & 1928 & 1906 & 1917 \\
\hline $\mathbf{T}_{3}$ & $\begin{array}{l}\text { VAM (ECOMAX-G) } \\
\text { @ } 2.0 \text { kg per acre }+ \\
100 \% \text { of } \\
\text { recommended "NPK" }\end{array}$ & 94.4 & 94.25 & 94.35 & 125 & 125.33 & 125.33 & 3.33 & 3.37 & 3.35 & 23.5 & 19.67 & 21.60 & 35.4 & 30.33 & 32.87 & 2236 & 2189 & 2212 \\
\hline $\mathbf{T}_{4}$ & $\begin{array}{l}\text { VAM (ECOMAX-G) } \\
\text { @ } 2.0 \text { kg per acre + } \\
100 \% \text { of } \\
\text { recommended } \\
\text { "NK" } \& 60 \% \\
\text { recommended "P" }\end{array}$ & 97.6 & 94.23 & 95.91 & 117 & 117.33 & 117.20 & 3.47 & 2.73 & 3.10 & 19.9 & 17.00 & 18.47 & 31.2 & 26.00 & 28.60 & 2061 & 1970 & 2016 \\
\hline $\mathbf{T}_{5}$ & $\begin{array}{l}\text { Untreated (100\% of } \\
\text { recommended } \\
\text { "NPK") }\end{array}$ & 93.4 & 95.45 & 94.43 & 111 & 105.00 & 107.77 & 2.93 & 2.60 & 2.77 & 16.7 & 14.00 & 15.33 & 24.4 & 22.33 & 23.37 & 1778 & 1700 & 1740 \\
\hline & $\mathrm{SE}(\mathbf{m})+/-$ & 1.5 & 2.07 & 1.78 & 3.93 & 4.11 & 3.60 & 0.13 & 0.16 & 0.07 & 0.44 & 1.23 & 1.01 & 1.7 & 1.30 & 1.60 & 91 & 88 & 84 \\
\hline & CD at $5 \%$ & N. S. & N. S. & N. S. & 15.41 & 12.47 & 10.93 & 0.51 & 0.49 & 0.21 & 1.74 & 3.73 & 3.06 & 0.51 & 3.93 & 4.86 & 356 & 268 & 254 \\
\hline
\end{tabular}


It is further revealed from the data that soil application of VAM (ECOMAX-G) + full "NK"\& 60\% "P" $\left(\mathrm{T}_{4}\right)$ or seed treatment with Azotobacter (AZOMAX) + full "PK"\& 75\% "N" $\left(\mathrm{T}_{2}\right)$ produced comparable seed cotton yield with that of $100 \%$ recommended "NPK" applied with these biofertilizers $\left(\mathrm{T}_{1} \& \mathrm{~T}_{3}\right)$, indicating $40 \%$ dose of "P" or $25 \%$ dose of " $\mathrm{N}$ " can be saved by using these biofertilizers without impact on yield and would be more profitable to the farmers.

Such improvement increase in the yield of fiber crops due to Azotobacter sp. inoculation in cotton has been reported earlier also (Anjum et al., 2007).

Sridevi and Ramakrishnan, 2010 reported similer result in cotton yield attributes, like number of sympodial branches, bolls etc., under increased 100 per cent NPK with VAM fungi inoculated plants.

Improvement in bolls formed and increase in boll weight and yield by Azotobacter treatment reported by Sangeeta Paul et al., 2011 in cotton.

The results of present investigation suggests that, among the various treatments, application of Azotobacter (AZOMAX) or VAM (ECOMAX-G) along with 100\% recommended dose of "NPK", produced significantly higher seed cotton yield compared to $100 \%$ recommended "NPK" alone. It is also revealed that $25 \%$ Nitrogen or $40 \%$ Phosphorus fertilizers dose could be saved through use of these biofertilizers without impact on yield and would be more beneficial to the farmers.

\section{References}

Anjum M. A., Sajjad M. R., Akhtar N., Qureshi M. A., Iqbal A., Jami A. R. and Mahmud- ul-Hasan. 2007.
Response of cotton to plant growth promoting rhizobacteria (PGPR) inoculation under different levels of nitrogen. Journal of Agricultural Research 45: 135-43.

Barea J. M. and Brown M. E. 1974. Effect on plant growth produced by Azotobacter paspali related to synthesis of plant growth regulating substance. Journal of Applied Bacteriology 37: 583-93.

Hafeez F. Y., Safdar M. E., Chaudhry A. U. and Malik K. A. 2004. Rhizobial inoculation improves seedling emergence, nutrient uptake and growth of cotton. Australian Journal of Experimental Agriculture 44: 61722.

Jackson R. M., Brown M. E. and Burlingham S. K. 1964. Similar effects on tomato plants of Azotobacter inoculation and application of gibberellins. Nature 203: 851-2.

Koranne, K.D. (1996). Cotton: R\&D gains urgency. In:Survey of Indian Agriculture (Ed. R. Ravi) National Press, Chennai, pp. 73-77.

Kumar, R., Gupta, P.P. and Jalali B.L. (2001). Impact of VA-mycorrhiza, Azotobacter and Rhizobium on growth and nutrition of cowpea. $J$. Mycol. Plant Pathol.,31: 38-41.

Malik B. S., Paul S., Sharma R. K., Sethi, A. P. and Verma O. P.2005. Effect of Azotobacter chroococcum on wheat (Triticum aestivum) yield and its attributing components. Indian Journal of Agricultural Sciences 75: 600-2.

Malik B. S., Paul S., Ahlawat A. K., Singh A. M. and Shivay Y. S. 2009. Productivity and quality of wheat spp. grown with different fertilization condition. Indian Journal of Agricultural Sciences 79: 636-40.

Marulanda A., Azcón R. and Ruiz-Lozano J. M., 2003. Contribution of six 
arbuscular mycorrhizal isolates to water uptake by Lactuca sativa plants under drought stress. Physiologia Plantarum 119: 523-533.

Panse, V.G. and Sukhatme P.V., 1978. Statistical Methods for Agricultural Workers. ICAR Publication, New Delhi.

Paul S. and Paul B. 2009. Azotobacter: Recent Advances. (in) Soil Microflora, pp 279-314. Gupta R K, Kumar M and Vyas D (Eds). Daya Publishing House, New Delhi

Sangeeta Paul, Maheshwar Singh Rathi and Satya Prakash Tyagi. 2011. Interactive effect with AM fungi and Azotobacter inoculated seed on germination, plant growth and yield in cotton (Gossypium hirsutum). Indian Journal of Agricultural Sciences 81 (11): 1041-1045.

Singh C. S. and Rana J. P. S. 2005. Arbuscular mycorrhizal fungi. (in) Advances in microbiology at IARI
1961-2004 pp 123-34. Kaushik B D (eds). Mounto publishing house, New Delhi.

Sridevi S. and Ramakrishnan K. 2010. The effect of NPK fertilizer and VAM fungi on the growth and yield of cotton (Gossypium hirsutum 1.) var. LRA- 5166. Recent Research in Science and Technology. 2(10): 39-41.

Tilak, K.V.B.R. and Singh G. 1994. Bofertilizer research gap and future needs. Fert. News, 39:11-17.

Tripathi, A., Rashmi Srivastava, Chaturvedi, C., Srivastava, B.K. and Singh H.B. (2005). Response of bitter gourd to mycorrhizal diversity for growth, yield and nutrient uptake.

Vijayakumar, B.S., Bhiravamurthy, P.V. and Anand M.G. (2000). VAM fungi association in Lycoperiscum esculentum L. grown in semi-arid tropical soils of Puttaparthy, A.P.J. Ecobiol., 12(1): 73-74.

\section{How to cite this article:}

Patke, N. K., R. S. Wankhade, A. A. Choudhary and Sonal Nage. 2020. Evaluation of Efficacy of Azotobacter (AZOMAX) and VAM (ECOMAX-G) on Cotton Yield Attributing Characters. Int.J.Curr.Microbiol.App.Sci. 9(08): 2870-2875. doi: https://doi.org/10.20546/ijcmas.2020.908.322 